\title{
CONTRIBUTION OF AGRO-ECOSYSTEM IN IMPROVING AGRICULTURAL RESILIENCE AMONG FARMERS IN WHITE NILE SUDAN
}

\author{
Reem Fadul Kabbar ${ }^{* 1}$, Esmail Alfadul 2, Abdelmoneim A. Babiker ${ }^{3}$ \\ ${ }^{* 1,2,3}$ Department Agricultural Extension \&Rural Development, Faculty of Agriculture, University \\ of Khartoum, Sudan, North Africa
}

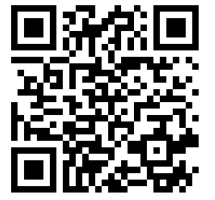

DOI: https://doi.org/10.29121/granthaalayah.v8.i8.2020.860

Article Type: Research Article

Article Citation: Reem Fadul

Kabbar, Esmail Alfadul, and

Abdelmoneim A. Babiker. (2020).

CONTRIBUTION OF AGRO-

ECOSYSTEM IN IMPROVING

AGRICULTURAL RESILIENCE

AMONG FARMERS IN WHITE NILE

SUDAN. International Journal of

Research -GRANTHAALAYAH, 8(8),

173-180.

https://doi.org/10.29121/granthaa

layah.v8.i8.2020.860

Received Date: 24 July 2020

Accepted Date: 27 August 2020

Keywords:

Agro-Ecosystem

Agricultural Resilience

Sudan

\section{ABSTRACT}

This paper was designed to assess contribution of agro-ecosystem after intervention in improving agricultural resilience among farmers in White Nile State of Sudan. The study was based on primary data collected from 200 farmers by a questionnaire. A stratified sampling method was followed to select 200 farmers. Descriptive statistics (frequency and percentage Model of agricultural resilience consisted of two important dependent variables income from agriculture and adaptive capacity of the farmers against the changes in agro-ecosystem. farmers had many practices to adapt with change in agro-ecosystem. The results of analysing the model of agricultural resilience discovered males as more resilient than females. The factors age, years of experience and years of education were found to increase agricultural resilience of the farmers. Moreover, farmers of sesame and peanut were more adaptive to the change in agro-ecosystem than farmers of the sorghum. The study also revealed that farmers benefited significantly from Khor Abu Habil Water. Regarding to the local knowledge of the farmers in the study area there were natural predators helping in defeating insects, the results discovered that negative relationship between the conflicts in the study area and the income from agriculture. The more conflict existing in the area the less income from agriculture will be achieved.

\section{INTRODUCTION}

Agriculture is a multi-faceted concept that contains a wide range of productive systems. Potential benefits and disadvantages of agriculture to ecosystem services will be mainly shaped by the typology of the agro-ecosystem, (FAO, 2011). Resilience is the capacity of a system, deal with change and continue to develop. It is capacity to use in shocks and crisis or climate change to spur renewal and innovative thinking. Resilience thinking embraces learning, diversity and above all the belief that humans and nature are strongly coupled to the point that they should be conceived of as one social-ecological system (Moberg and Simonsen, 2013). Resilience is not just about the ability to maintain or return to a previous state; it is about adapting and learning to live with changes and uncertainty. There are three types of capacity that are important in helping people do this: (i) absorptive capacity, that is, the ability to cope with, and absorb the effects of shocks and stresses (ii) adaptive capacity, that is, the ability of individuals or societies to adjust and adapt to shocks and stresses, but keep the overall system functioning in broadly the same way - for instance when a household decides to diversify its crops in order to respond to changing weather conditions;

(C) 2020 The Author(s). This is an open access article distributed under the terms of the Creative Commons Attribution License, which permits unrestricted use, distribution, and reproduction in any medium, provided the original author and source are credited. 
(iii) transformative capacity, that is, the ability to change the system fundamentally (Béné , 2013).Agricultural resilience is about providing farmers to absorb and recover from shocks and stresses to their agricultural production and livelihoods. (Grady, 2011). Increasing resilience can be achieved by reducing vulnerabilities and increasing adaptive capacity. This can be achieved by reducing exposure, reducing sensitivity and increasing adaptive capacity, for every type of risk. In this paper focus was on how the intervention of Tandalti dam - built in 2007 at the pathway of Khor Abu Habilcan - support agricultural activities by many changes in Agro-Ecosystem happened which had an impact on agricultural production. Therefore, this paper is seeking to assess Agro-Ecosystem in improving agricultural resilience among farmers in the Semi-arid Khor Abu Habil, Sudan.

\section{RESEARCH METHOD}

The primary data used in this paper were collected from the respondents by using a questionnaire. The study included all farmers in Tandalti locality on the pathway of Khor Abu-Habil $60 \mathrm{~km}$ north of the Tandalti Dam and 40 km south Tandalti Dam. Farmers were 2000 distributed to 32 villages.

A stratified sample was used to select the sample size. Descriptive statistics (frequency and percentage) has been used to describe the characteristics of the respondents. STATA Software was used to implement the Ordered Logistic Regression Model. The purpose of the model was to assess the contribution of agro-ecosystem in improving agricultural resilience in semi-arid Khor Abu Habil. Various Inflation Factors (VIF) was determined to know how much the variance (the square of the estimate's standard deviation) of an estimated regression coefficient is increased because of co-linearity. (VIF) was 1.74 and that less than 2, which was acceptable. R-squared was 0.8017 that means the15 independent variables were going to explain the two-dependent variable (income from agriculture and adaptive capacity of farmers, which represent the agricultural resilience in the model) by $80 \%$ and with standard error $20 \%$. The Probability of the model was less than 0.05 and it was 0.001 , which was highly significant that means the model was proper.

Table 1: Assumptions Model

\begin{tabular}{|c|c|c|}
\hline Variables & $\begin{array}{l}\text { Expected } \\
\text { Sign }\end{array}$ & Assumptions \\
\hline \multicolumn{3}{|r|}{ Socioeconomic Variables } \\
\hline Age & - & Increasing age will reduce the agricultural resilience of the farmers \\
\hline Gender & + & Male are more resilient than female \\
\hline Years of Experience & + & $\begin{array}{l}\text { Increasing years of experience will increase the agricultural resilience of } \\
\text { the farmers }\end{array}$ \\
\hline Years of Education & + & $\begin{array}{l}\text { Increasing years of education will increase the agricultural resilience of } \\
\text { the farmers }\end{array}$ \\
\hline Agricultural Pattern & + & $\begin{array}{l}\text { Farmers of flooding agriculture are more resilient than traditional } \\
\text { farmers }\end{array}$ \\
\hline \multicolumn{3}{|r|}{ Agro ecosystem Variables } \\
\hline $\begin{array}{l}\text { Productivity of } \\
\text { Sesame }\end{array}$ & + & Sesame will contribute positively on the agricultural resilience \\
\hline $\begin{array}{l}\text { Productivity of } \\
\text { Peanut }\end{array}$ & + & Peanut will contribute positively on the agricultural resilience \\
\hline $\begin{array}{l}\text { Productivity of } \\
\text { Sorghum }\end{array}$ & + & Sorghum will contribute positively on the agricultural resilience \\
\hline Agricultural Residual & + & $\begin{array}{l}\text { Agricultural residual will contribute positively on the agricultural } \\
\text { resilience }\end{array}$ \\
\hline Natural Fertilization & + & $\begin{array}{l}\text { Natural fertilization will contribute positively on the agricultural } \\
\text { resilience }\end{array}$ \\
\hline $\begin{array}{l}\text { Water of Khor Abo } \\
\text { Habil }\end{array}$ & $+/-$ & $\begin{array}{l}\text { Water will contribute positively or negatively on the agricultural } \\
\text { resilience }\end{array}$ \\
\hline Soil Fertility & + & Soil Fertility will contribute positively on the agricultural resilience \\
\hline
\end{tabular}


Reem Fadul Kabbar, Esmail Alfadul, and Abdelmoneim A. Babiker

\begin{tabular}{|c|c|c|}
\hline Excrement of Animals & $+/-$ & $\begin{array}{c}\text { Excrement of animals will contribute positively on the agricultural } \\
\text { resilience }\end{array}$ \\
\hline Natural Predators & $+/-$ & $\begin{array}{c}\text { Natural Predators will contribute positively or negatively on the } \\
\text { agricultural resilience }\end{array}$ \\
\hline Existing of Conflict & - & $\begin{array}{c}\text { Conflicts in the study area will contribute negatively on the agricultural } \\
\text { resilience }\end{array}$ \\
\hline
\end{tabular}

\section{RESULTS AND DISCUSSIONS}

Table 3.1: Agricultural Resilience Model

\begin{tabular}{|c|c|c|c|c|c|c|c|c|}
\hline & Age & Gender & $\begin{array}{c}\text { Years } \\
\text { Educatio } \\
\mathrm{n}\end{array}$ & $\begin{array}{c}\text { Years of } \\
\text { Experienc } \\
\mathrm{e} \\
\end{array}$ & $\begin{array}{l}\text { Agricultura } \\
\text { l Pattern }\end{array}$ & $\begin{array}{c}\text { Productive } \\
\text { Sesame }\end{array}$ & $\begin{array}{l}\text { Productiv } \\
\text { e Peanut }\end{array}$ & $\begin{array}{c}\text { Productiv } \\
\text { e of } \\
\text { Sorghum }\end{array}$ \\
\hline Income & .11915 & 1.108 & 5.063 & 0.7458 & 03063 & 1.73374 & 0.1005 & 0.87460 \\
\hline from & 1.5215 & 51.30 & 46.10 & 97.50845 & 0.0437 & 2.723970 .00 & 3.452 & 2.208432 \\
\hline $\begin{array}{c}\text { agricultur } \\
\text { e }\end{array}$ & 0.438 & 0.036 & 0.278 & 0.01 & 0.94 & 0 & 0.000 & 0.000 \\
\hline $\begin{array}{l}\text { Adaptive } \\
\text { capacity }\end{array}$ & $\begin{array}{c}-.00315 \\
.00516 \\
0 \\
0.61\end{array}$ & $\begin{array}{c}.15641 \\
0 \\
.17143 \\
0 \\
0.363\end{array}$ & $\begin{array}{c}0111915 \\
.0185294 \\
0.546\end{array}$ & $\begin{array}{c}.8047 \\
3.7459 \\
0.201\end{array}$ & $\begin{array}{c}.02268 \\
.17039 \\
0.894\end{array}$ & $\begin{array}{c}000033 \\
.000204 \\
0.869\end{array}$ & $\begin{array}{c}.000031 \\
.000249 \\
0.901\end{array}$ & $\begin{array}{c}-.000114 \\
.0001648 \\
0.492\end{array}$ \\
\hline
\end{tabular}

\subsection{AGRICULTURAL RESILIENCE MODEL CON}

\begin{tabular}{|c|c|c|c|c|c|c|c|}
\hline & $\begin{array}{c}\text { Agric. } \\
\text { Residual }\end{array}$ & $\begin{array}{c}\text { Soil } \\
\text { Fertility }\end{array}$ & $\begin{array}{c}\text { Burning } \\
\text { Excrement of } \\
\text { Animals }\end{array}$ & $\begin{array}{c}\text { Natural } \\
\text { Predators }\end{array}$ & $\begin{array}{c}\text { Existence } \\
\text { of Conflict }\end{array}$ & $\begin{array}{c}\text { Natural } \\
\text { Fertilization }\end{array}$ & $\begin{array}{c}\text { Benefit } \\
\text { from } \\
\text { Khor's } \\
\text { Water }\end{array}$ \\
\hline Income from & 23.8221 & 500.35 & 0.00125 & 3375.1 & -10.6873 & 4.200 & 0.4208 \\
agriculture & 111.155 & 423.80 & .02680 & 5622.0 & 427.539 & 0.0392 & 3.9211 \\
& 0.831 & 0.239 & 0.001 & 0.549 & 0.016 & 0.010 & 0.051 \\
\hline Adaptive & -.21949 & -.01373 & 0.0358 & .00387 & -311.42 & 42.014 & 208.14 \\
capacity & .428430 & .16395 & 0.39581 & 0.0008 & 797.427 & 392.145 & 92.184 \\
& 0.609 & 0.933 & 0.062 & 0.02 & 0.142 & 0.102 & 0.187 \\
\hline
\end{tabular}

Source: Field Survey (2018)

\subsection{DISCUSSION OF SOCIOECONOMIC VARIABLES}

\subsubsection{FACTOR OF AGE}

Other socioeconomic factors such as age, which contributed positively on agricultural income, but it was not significant (0.438) at 0.05 significance level and coefficient $(0.11915)$ as table 5.1 showed. That means farmer will gain more money from agriculture when getting older. The sign of coefficient of the age was against to the hypothetical sign of age in the table of the expectation sign. In addition, age with adaptive capacity was not significant (0.61) and coefficient (-.00315) as table 3.1 showed. The sign of the coefficient (-.00315) was negative which means the young farmers were more adaptive to the changes in agro-ecosystem rather than old farmers. As a result, the young farmers were more resilient than old farmers. 
Contribution of Agro-ecosystem in Improving Agricultural Resilience among Farmers in White Nile Sudan

\subsubsection{FACTOR OF GENDER}

Many factors affected the agricultural resilience in semi-arid Khor Abu Habil positively and negatively. Gender was one of these factors. The income from agriculture will be increased to the direction of the male rather than female. The reason behind this was mentioned previously in table 3.1 that the men had more effort in agriculture than female in study area. In addition, men were responsible for the marketing process. Besides that, women in study area had more responsibility beside their work in agriculture such as cooking and cleaning, taking care of children and other housing staff. On one hand, the variable of gender with income from agriculture was significant (P. value 0.036 ) at 0.05 significance level with coefficient (1.108). However, also the interpretation was going in the direction of the male. The numeric interpretation that every man will gain 110.8 SDG from agriculture more than woman did. On the other hand, male were more adaptive to change in agro ecosystem rather than female but it was not significant (0.363) see table 3.1 Therefore males were more resilient than females.

\subsubsection{FACTOR OF YEARS OF EXPERIENCE}

Years of experience of agricultural practices affected the agricultural resilience significantly (0.01) at 0.05 significance level. The coefficient was $(0.7458)$ and it was positive. That mean the income from agriculture will be increased when the farmer had more experience in agricultural practice. Other numeric interpretation when the farmer had one more experience year the income from agriculture will increase by 74.58 SDG. On the other hand, the coefficient of years of experience and adaptive capacity was positive (4.8047) and it was not significant (0.546) as in table 3.1Therefore, the capability of the farmers to adapt with changes in agro-ecosystem will be increased when the farmers have more years of experience in agriculture. Therefore, farmers will be more resilient with more years of experience in agriculture.

\subsubsection{FACTOR OF AGRICULTURAL PATTERN}

As table 5.1 showed, there were two main agricultural patterns in the study area. Flooding agriculture and rain fed agriculture. Agricultural pattern with income from agriculture was not significant (P. Value 0.94) at 0.05 significance level but the coefficient was positive $(0.03063)$ see table 3.1 . However, the interpretation was going to the direction of flooding agriculture, the more flooding agriculture be practiced the greater income from agriculture be achieved. Also the interpretation of agricultural pattern with adaptive capacity, which was not significant ( $P$. value 0.894 ) at 0.05 significance level with positive coefficient $(0.02268)$, was going to the direction of the flooding agriculture. The farmer of flooding agriculture were more adapted to the change in agro-ecosystem. Therefore, farmers of flooding agriculture were more resilient than rain fed farmers, who grow away of the pathway of Khor Abu Habil. The reason behind this was that the rain fed farmers were more vulnerable to hazards of agro ecosystem especially drought and sand creeping. In addition, they were more adapted to herbicide and pesticide that rain fed farmers see table 5.2.

\subsubsection{FACTOR OF YEARS OF EDUCATION}

The variable of years of education has an effect on the agricultural income positively, but it was not significant (0.278) with positive coefficient (5.063). Which means the income from agriculture will increase by increasing the years of education. Other numeric interpretation, increasing one year of education will increase the income from agriculture by 506.3SDG. In addition, the adaptive capacity of the farmers will increase by increasing the years of education. The conclusion was that the more educated famers the better resilient status. This result was confirmed by a study in Zimbabwi which was conducted by (Ellen Chigwanda, 2016). The study had mentioned that Education has a great contribution on building resilience of the community. Therefore, having an education can prepare a girl to cope better with droughts and climate change. This study specifically focused on how droughts lead to girls missing school and to explore the interplay between girls' education and climate change. 
Reem Fadul Kabbar, Esmail Alfadul, and Abdelmoneim A. Babiker

\subsection{DISCUSSION OF AGRO ECOSYSTEM VARIABLES}

\subsubsection{CROPS PRODUCTIVITY}

Sesame in Sudan is considered one of the most important cash crops. It had significant contribution on the income from agriculture in study area. According to table 5.3,38.7\% of the farmers grew the sesame. The coefficient was 1.733 and p. value was 0.000 at 0.05 significance level as in table 3.1 The numeric interpretation of this result is when increasing sesame productivity by one kg per fed will increase the income from agriculture by 173.3 SDG.

Sorghum was one of the most important crops to farmers in the study area. It was used to feed themselves and their animals. It had significant contribution on the income from agriculture in study area. According to table 5.3 that $34.7 \%$ of the farmers grew the sorghum. The coefficient was 0.8746 and p. value was 0.000 at 0.05 significance level as in table 3.1. The numeric interpretation was when increasing sorghum productivity by one kg per fed it will result in income increase from agriculture by 87.4 SDG.Peanut was one of the cash crops in the study area. According to group discussion, many farmers grew the peanut for marketing reason. In addition, some of the crop is used to feed themselves and their animals. It had significant contribution on the income from agriculture in study area. According to table 5.3 that $38.7 \%$ of the farmers grew the peanut. The coefficient was 0.1005 and p. value was 0.000 at 0.05 significance level as in table 3.1. The numeric interpretation is that increasing peanut productivity by one kg per fed will increase the income from agriculture by 100 SDG. Similarly, in term of variable of adaptive capacity the signs of the coefficient of farmers of sesame and peanut were positive ( 0.000033 and 0.00031 consequently). And the sign of sorghum was negative $(-0.000114)$ as in table 3.1Therefore the conclusion will be that farmers of sesame and peanut were more adaptive to the change in agro-ecosystem rather than farmers of the sorghum, but this was not significant. The reason behind this may be the pests that threatened the crop recently as mentioned in table 5.3. As a result agricultural productivity (sesame and peanut) were contributed significantly in agricultural resilience of the farmers. The more agricultural production will be gained the more resilience will be built.

\subsubsection{FACTOR OF NATURAL FERTILIZATION}

Recently animals in the study area were introduced to the crops rotation system see table 5.4. However, farmers benefited from agricultural residual as dry forage to feed animals, which produce natural fertilization. The coefficient was 4.200 and the p. value was ( 0.010 at 0.05 significant level). According to this result, using natural fertilization contributed significantly in the income from agriculture. The more natural fertilization will be used the greater income will be gained. Other numeric interpretation is that using one unit of natural fertilization per fed will increase the income from agriculture by 420 SDG. Therefore, natural fertilization supported the agricultural resilience in the study area.

\subsubsection{FACTOR OF BURNING EXCREMENT OF ANIMALS}

In the time being many insects and pests had appeared in the study area. There were more than $74 \%$ of farmers observed a new pest and insects in the area since the Tandalti Dam was established in 2007 (see table 5.5). Farmers had their own ways to protect themselves, crops and their animals. Burning excrement of animals was a successful way. The coefficient was 0.00125 with positive sign and the p. value was ( 0.010 at 0.05 significant level). That means burning excrement of animals contributed significantly in the income from agriculture. Hence, the technique of burning excrement of animals support the agricultural resilience in the study area. The more pests and insects being fought by burning excrement of animals, the greater agricultural resilience will be built.

\subsubsection{FACTOR OF KHOR'S WATER}

Khor Abu Habil carries water only periodically during the rainy season. It originates in the Nuba Mountains and flows along a pre-defined pathway of channels (Seifelislam, 2017). The Khor water support the flooding agriculture, which was practiced by more than $54 \%$ of the farmers in the study area and was considered as the main agricultural pattern (see table 5.1). The sign coefficient was positive and the p. value was significant (0.05 at 0.05 significant level) see table 3.1. Therefore, Khor's water had a contribution on the resilience of the farmers in the study area. This 
Contribution of Agro-ecosystem in Improving Agricultural Resilience among Farmers in White Nile Sudan

result was a confirmed result to the fact that farmers were benefited from the flooding agriculture mentioned previously hence, the conclusion that Khor Abo Habil supported the agricultural resilience significantly.

\subsubsection{FACTOR OF NATURAL PREDATORS}

Regarding to the local knowledge of the farmers in the study area there were natural predators helping in defeating the insects, which was significant ( 0.02 at 0.05 significant level) with adaptive capacity. The interpretation was going in the direction of farmers who had a strong adaptive capacity. Natural predators will be used more by the strong adaptive farmers with the change in agro-ecosystem. In the same way, natural predators contributed positively with income from agriculture. However, it was not significant. Therefore, the conclusion was the natural predators contributed positively on the agricultural resilience of the farmers in the study area.

\subsubsection{FACTOR OF CONFLICT IN THE STUDY AREA}

Recently there was a conflict in the study area between farmers and agro pastoralist. More than 59\% of the farmers suffered from such conflict as table 5.6 showed. This conflict had negative effect on the income from agriculture and at the same time on the community stability. The results discovered that negative relationship between the conflict in the study area and the income from agriculture by determine the negative coefficient -10.68 . Meanwhile the relation was significant ( 0.016 at the 0.05 significant level). Therefore, the more conflict existing in the area the less income from agriculture will be achieved.

\section{CONCLUSIONS AND RECOMMENDATIONS}

The agricultural resilience of farmers in semi-arid Khor Abu Habil was built through enhancing the agricultural productivity and increasing the capability of farmers to adapt with changes in agro-ecosystem. Agro-ecosystem on Khor Abu Habil helped farmers to be resilient. Males were more resilient than females. In addition, by increasing age, years of experience and years of education agricultural resilience of the farmers will be increased. Sesame, Peanut, and Sorghum contributed significantly on agricultural resilience. Farmers of flooding agriculture were more resilient than traditional farmers. Using natural fertilization and natural predators helped farmers to be more resilient in the study area. Existing conflict between the pastoralists and farmers in the study area affected negatively the resilience of the community in the study area.

\section{APPENDICES}

Table 5.1: Distribution of the Respondents by Agricultural Pattern

\begin{tabular}{|c|c|c|}
\hline Agricultural pattern & Frequency & Percent \\
\hline Traditional rain fed & 4 & 1.8 \\
\hline mechanized rain fed & 41 & 18.9 \\
\hline flooding agriculture & 118 & 54.4 \\
\hline Traditional rain fed and flooding agriculture & 25 & 11.5 \\
\hline Traditional rain fed and mechanized rain fed & 29 & 13.4 \\
\hline Total & 217 & 100.0 \\
\hline
\end{tabular}

Source: Field Survey (2018)

Table 5.2: Methods of Agricultural Pest Control before and after the Construction of the Tandalti Dam

Source: Field Survey (2018)

\begin{tabular}{|c|c|c|c|c|}
\hline Methods of Pest Control & Before & After & Test & P .value \\
\hline Screaming and Al-Khial & $55.7 \%$ & $46.0 \%$ & & \\
\hline Using pesticide Cevien & $8.5 \%$ & $19.0 \%$ & McNemar & 0.000 \\
\hline Burning the excrement of animals & $14.6 \%$ & $17.1 \%$ & & \\
\hline Al-Sheikh & $17 \%$ & $10 \%$ & & \\
\hline Ministry of Agriculture & $3.8 \%$ & $10 \%$ & & \\
\hline
\end{tabular}


Table 5.3: Distribution of the Respondents by the Main Crops are Grown by Farmers

\begin{tabular}{|c|c|c|}
\hline Main Crops & Frequency & Percent \\
\hline Sesame and Peanuts & 84 & 38.7 \\
\hline Sesame and Sorghum & 74 & 34.1 \\
\hline Vegetables & 59 & 27.2 \\
\hline Total & 217 & 100 \\
\hline
\end{tabular}

Source: Field Survey (2018)

Table 5.4: Distribution of the Respondents by Benefits from the Agricultural Residues

\begin{tabular}{|c|c|c|}
\hline Benefits from the Agricultural Residues & Frequency & Percent \\
\hline Sale in the market & 47 & 22.5 \\
\hline keeping to animals & 146 & 69.9 \\
\hline Energy & 8 & 3.8 \\
\hline Building house & 8 & 3.8 \\
\hline Total & 217 & 100 \\
\hline
\end{tabular}

Source: Field Survey (2019)

Table 5.5: Distribution of the Respondents by Using of Indigenous Knowledge in Determining Rain Time

\begin{tabular}{|c|c|c|}
\hline Using of indigenous knowledge in & Frequency & Percent \\
\hline Using of indigenous knowledge in deterring rain time & 135 & 62.2 \\
\hline Not using of indigenous knowledge in determining rain time & 82 & 37.8 \\
\hline Total & 217 & 100.0 \\
\hline
\end{tabular}

Source: Field Survey (2018)

Table 5.6: Existence of the Conflicts in the Area

\begin{tabular}{|c|c|c|}
\hline Conflicts in the Area & Frequency & Percent \\
\hline There are conflicts in the area & 129 & 59.4 \\
\hline There are on conflicts in the area & 88 & 40.6 \\
\hline Total & 217 & 100.0 \\
\hline
\end{tabular}

Source: Field Survey (2019)

\section{SOURCES OF FUNDING}

This research received no specific grant from any funding agency in the public, commercial, or not-for-profit sectors.

\section{CONFLICT OF INTEREST}

The author have declared that no competing interests exist.

\section{ACKNOWLEDGMENT}

None.

\section{REFERENCES}

[1] Béné, C.; Wood, R.G.; Newsham, A.; Davies, M. (2012). Resilience: New Utopia or New Tyranny? http://www.ids.ac.uk/events/resilience-new-utopia-or-new-tyranny.

[2] Ellen Chigwanda, 2016 A Framework for Building Resilience to Climate Change through Girls' Education Programming, Centre of Universal Education, Brokings, Zimbabwi 
[3] FAO, 2011. Payments for Ecosystem services and Food Security, Food and Agriculture Organization of the United Nations, Office of Knowledge Exchange, Research and Extension, FAO, Italy 2011.

[4] F.; Simonsen, S.H. (2013). What is resilience? An introduction to social ecologicalre sea rc. http ://www.Sto ckholmresi l ience.org/21/research/what-is-resilience.html

[5] Seifelislam, A. (2017). Detection of Land Cover and Land Use Changes in the Semi-Arid Khor Abu Habil region (Sudan) by means of Remote Sensing, GIS and socioeconomic data". MA thesis. RWTH Aachen University 